\title{
ACADEMIES OF HATRED
}

\author{
Adam Chmielewski \\ Wroclaw University, Institute of Philosophy \\ Pl. Uniwersytecki 1 \\ 50-137 Wrocław, Poland \\ E-mail: chmielew@szermierz.uni.wroc.pl
}

Received on 30 August, 2013; accepted on 30 April, 2014

doi:10.13165/SMS-14-6-1-11

\section{Introduction}

The paper is a case study of the recent increase of the exclusivist phenomena in Poland. In reference to several incidents staged by extremist grouping in the public domain, in particular the disruption of a public lecture by philosopher Zygmunt Bauman, the author of this paper interprets these activities as a symptom of the rise and entrenchment of exclusionary xenophobic ideologies among the Polish youth. In an attempt to explain the present wave of extremism in Poland, the author points out to the authoritarian tendencies displayed by Polish political parties, as well as despotic leanings on the level of local government. The author also claims that these features of the Polish political culture negatively affect the citizens' participation in democratic deliberation on public matters. He also points out to a specific exclusionary political aesthetics which now determines both the contents and form of acceptable political and cultural beliefs. Xenophobic groupings take advantage of this dominant political aesthetics in order to stage their racist public performances with impunity. The transgressive nature of their activities finds its expression both in the racist hate-speech they employ and promote, as well as in their disruptive character. They have, however, learned to escape from persecution through skillfully blending some elements of the officially promoted ideologies into their racist message.

Socialinių mokslų studijos / Societal Studies

(C) Mykolo Romerio universitetas, 2014

(C) Mykolas Romeris University, 2014
ISSN 2029-2236 (print), ISSN 2029-2244 (online) http://www.mruni.eu/lt/mokslo_darbai/SMS/ http://www.mruni.eu/en/mokslo_darbai/SMS/ 


\section{The Event}

The disruption of Zygmunt Bauman's lecture at the University of Wrockaw on June 22, 2013 by the National Rebirth of Poland ${ }^{1}$ has been one of many similar events recently to have taken place across Poland.

The lecture was organised by the Friedrich Ebert Stiftung, an intellectual branch of the German Social Democratic Party, an independent Ferdinand Lasalle Centre of Social Thought and the Department of Social and Political Philosophy of the University of Wrockaw which the author of this paper chairs. Zygmunt Bauman, presently the most renowned Polish scholar in the world, was the main speaker. Another hero of the event was Ferdinand Lassalle, a Breslauer and a student of the university in Wrocław in its German times, Karl Marx's collaborator and the founder of the German social democratic party, whose remains rest at the Jewish Cemetery in Wrocław. The occasion was to commemorate the 150th anniversary of the first social democratic party in the world, established by Lassalle. The topic of the meeting was the ideals of the Left, old and new, and the challenges the leftist movement faces nowadays, in the period of a new stage of capitalism and its crisis.

By getting involved in the organization of Bauman's lecture at the University of Wrocław, the author of the present paper was hoping for a scholarly and critical debate about the future of Poland, and the world, a scholarly one, because the debate was to be inspired by an eminent thinker, and a critical one, because an opportunity for a renewal of egalitarian thinking about economy and politics, now eagerly seized in many parts of the world, is being met in Poland with disdain from political parties which duplicitously present themselves as leftist, and with ridicule or repression from the remaining political parties.

It was the second visit by Bauman to the Polish city of Wrocław that the author of this paper had organised. The first one took place in 1996. On that earlier occasion no one expected any disturbances to occur during a series of academic and public appearances by the author of Postmodern Ethics. There were also no incidents when Bauman spoke in Wrocław to the European Congress of Culture in September 2011, soon after the city was awarded the title of European Capital of Culture 2016.

What sort of changes occurred in the meantime, in both the Wroclaw's and Polish public space, which made possible the disruption of Bauman's lecture and many other similar disturbances? These incidents cast a sinister, dark brown shadow upon the image of Poland in the world. But there is one benefit to be drawn from them. It is that the above question cannot be shunned any longer.

\section{The Set-Up}

Designed in the way described above, the academic meeting has been viewed by some as a fusion of Jewishness, Germanness and Leftishness. Since it was also open

1 Narodowe Odrodzenie Polski; hereafter referred to as NOP. 
to the public, it was perceived by the local xenophobes as an incitement to a set-up ${ }^{2^{*}}$. For Bauman is not only a Polish scholar of great stature in the world and an author quoted in many disciplines, he was also a military officer of the Polish army during the Stalinist period. He is also a Jew, just as Ferdinand Lassalle was. Also, for the past two decades the ideals of the Left have been construed as an ideological foundation of the violent communist regime which murdered Polish patriots, and presented as a source of an extreme evil and of the enslavement of the country.

Just before the commencement of the meeting, quite unexpectedly, the mayor of Wrockaw arrived. The organizers of the event invited him to welcome the guest as the host of the city. He managed to say only the following: "I am Rafał Dutkiewicz. To those who do not yet know it, I would like to say that I am the mayor of this city". In response, about a hundred of the members of the NOP rose from their seats, unfolded a huge banner saying "NOP/Śląsk Wrocław", and started howling, yelling, chanting and vilifying the guest speaker, the organizers and the mayor alike.

It needs to be said that the soccer club of Śląsk Wrocław, the current holder of the championship of the Polish soccer league, is being generously supported by the local municipality under this mayor. Among the chants, which were thrown into mayor's face by the extremist soccer hooligans, was a slogan about the memory of the "excommunicated soldiers". Those soldiers were members of the Polish underground who did not become reconciled with the communist take-over of the post-war Poland, were persecuted by the communist regime and were banned from the collective memory until 1989. They symbolize a moral and political attitude which is rather close to the mayor's political views: the municipality ruled by him for the past 11 years has recently erected a monument to one of them, a cavalry officer Witold Pilecki. This material expression of the aesthetic politics of the city aligns well with the political aesthetics dominant in the whole country. Despite the official rhetoric of pluralism, the canons of this aesthetics dictate political tastes in Poland in a way, which is rather impossible and unwise to ignore.

\section{Canonisation and Escalation}

The development of radicalism in Wrocław has been documented carefully for some time now. It has been the subject of a disturbing report by the local Nomada Foundation; everyday xenophobic attitudes have been provocatively revealed in an experiment conducted by the pupils of one of the high schools in the city. There is no doubt that radical groupings in the city act ever more boldly and brazenly. About two

2 "This seems to be the closest possible translation of the Polish soccer hooligans' term "ustawka", which refers to a collective fight taking place in an agreed place and time between two antagonized groups of supporters of different soccer teams, resulting usually in many injuries on both sides, and quite often in fatalities.

3 Sląsk Wrocław is a name of the local soccer club, which is currently the champion of the Polish National Soccer League. 
months earlier, they achieved a significant success in preventing Daniel Cohn-Bendit, a member of the European Parliament, from lecturing at the University of Wrockaw on April 24, 2013. They have exerted a pressure on the organizers of that event and Cohn-Bendit himself, by calling upon everyone to protect their children from the paedophile. At the last moment, Cohn-Bendit cancelled his journey to Wrocław.

The so-called nationalists in Wrocław and in Poland have been encouraged especially since the moment of canonisation of their activities by Jarosław Kaczyński, the leader of the main opposition party in Poland, Prawo i Sprawiedliwość [Law and Justice]. For after a group of soccer supporters staged a violent brawl following a soccer match in Warsaw and were prosecuted by the police as well as criticised by the government officials, Kaczyński extended to them an ideological and political protection by calling them... genuine patriots. Ever since, undisturbed by law, they pick fights at soccer stadiums, disrupt lectures and political meetings, light fires at the doors of people whom they consider alien, cut off other people's hands by machetes, etc. Events of that nature appear with disturbing frequency in the Podlasie region. A Centre of the Muslim Culture has been attacked in Białystok; a fire has been set at the door of the apartment of a Polish-Pakistani couple living in the same city; a synagogue in the village Orla has been defiled by swastikas; Lithuanian monuments and signs have been covered by graffiti in Puńsk; in Jedwabne, where, after the village has been taken over by the German army, the local Polish community has burned alive their Jewish neighbours on July 10, 1941, someone painted swastikas and a slogan "I do not apologise for Jedwabne" on the monument commemorating 340 victims of the pogrom. An actor playing a leading role in a movie about the genocide in Jedwabne has become an object of racist hate-speech. Finally, a huge banner saying "Kneel down the Lithuanian peasant before the Polish Lord!" was exposed by the Polish fans during a football match of Lech Poznan and Žalgiris Vilnius, which added new tensions to the already strained Polish-Lithuanian relations.

Thanks to Kaczyński, the Polish xenophobes have usurped for themselves both the roles of judges of history and executioners, the sentences being carried out summarily, according to their own interpretation of the dominant canons of the political aesthetics. The leader of the Law and Justice has strengthened them in their truth. The power of their conviction and the political protection give them a force which cannot be matched by any other political moment in present-day Poland.

Interestingly, however, they are being supported not only by the Law and Justice. They have also received a very strong material support from the present government of Platforma Obywatelska [Civil Platform].

\section{The Political Soccer}

The rules of ancient democracy are said to have been modelled upon the principles of the Olympic Games. Just as warring Greek tribes temporarily suspended their mutual animosities at the time of the Olympic Games and sent their representatives 
to Olympic arenas in order to continue their wars in a vicarious form in various sport disciplines, so in democratic Athens each local community sent their representatives to the Assembly to haggle for local interests on their behalf.

In present-day Poland, the ties between sports and politics are much more intimate than that. For after one peels off all empty rhetoric and political imagery, it becomes rather difficult to dispel the impression that the Civic Platform's project of modernization of the country and the promotion of its interests exhausted itself, literally, in the organization of the European soccer championship in 2012. Setting subjective impressions aside, however, no one can deny that the Civic Platform, which has been ruling the country for the past seven years, displayed the greatest political energy as long as it was preparing the whole country for this spectacle, and lost it, immediately and completely, after the show was over.

Accordingly, Poland owes to this party more than two thousand (!) small sports playgrounds, located in almost every local community. They are known as Little Eagles and cost 1233477 Polish zloty each [373781 USD]. Their aim is not only to train the young soccer talents, but also to fill the leisure of the young, who have now the opportunity to enjoy it more than enough as 30 percent of them have no jobs. We owe to this party also four large cutting-edge stadiums in Gdańsk, Poznań, Warsaw and Wrocław, as well as barely passable roads built in order for us to be able to drive to them, even though, as yet, two years after their near-completion, there is really no good reason to do so.

It is difficult to dispel the impression that the Civic Platform never intended to govern the country in a democratic manner, through some kind of a covenant with society. It just wanted to manage and administer society by means of sports. Conceiving politics as a spectacle, the party fused politics with sports in an unprecedented way. Apparently, the leadership of the party assumed that the Little Eagles and the stadiums will become centres of sporting rivalry, entertainment and cultural events, venues to excite positive passions, and to discharge them. They seem to have assumed also, apparently judging after themselves ${ }^{4}$, that through holding the EURO 2012 in Poland, they would receive a powerful means of promotion of the country in Europe and in the world. They seem to have thought, too, that in this way they will acquire a powerful instrument to manage human masses, their leisure, emotions and thoughts.

On all these accounts, the Civic Platform suffered a major defeat because their assumptions turned out to be erroneous. It is, moreover, rather surprising to see a conservative party working upon such assumptions, for they are reeking with optimism untypical of the conservative attitude, which is an important strand within its ideology. The soccer infrastructure, by far the most important contribution of this party to the growth of Poland, has now become a symbol of the failure of its modernization project. 
Managing human masses by means of stadiums, a political technique employed prominently in the ancient Rome has its known limitations. One of them is that sport creates strong divisions between "us" and "them". The divisions thus fashioned are focused upon sports rivals and are symbolised by differing colours marking the armies of such substitute wars. Sport as a vicarious war enables to discharge the passions aroused by rivalries in the controlled manner. This, however, works well in civilised countries, in which their populations, as well as their authorities, are still capable of grasping the difference between sports and politics. Presently, even the Brazilian authorities, a country of the so-called Third World and a perennial soccer world champion, are now receiving a painful lesson of the difference from its own people.

The leaders of the Civic Platform have been apparently using outdated textbooks for political marketing. Despite the perfection of the instruments designed to manipulate public passions, they remain unpredictable. The Civic Platform has been acting as if they have forgotten about this critical fact. They have apparently forgotten also about the unparalleled wisdom of the great Polish philosopher and the most successful Polish soccer coach ever, Kazimierz Górski, who famously said that in the game of soccer "the ball is round and there are two goals in it".

As a result of these astounding oversights on the part of the Civic Platform, the passions of the soccer supporters, for whom this party has laboriously built the stadiums, have been effortlessly hijacked by the Law and Justice and are now being informed according to the xenophobic ideology rather than the conservative-liberal one. In other words, the political soccer match arranged by the Civic Platform for the whole nation has been easily won by opposition leader Jarosław Kaczyński. An unequalled champion of political acrobatics, Kaczyński has shot a penalty goal against Tusk without even going onto the pitch. It is a wholly different matter, though, whether he will be able to benefit from his victory.

By undertaking the modernization project by means of soccer, the Civic Platform has transformed a huge stream of taxpayers' money into an expensive concrete infrastructure instead of devoting themselves to deliberating how to build instruments of inclusion of the human masses, which for the past two decades have suffered economic and social exclusion. This project enriched the bosses - though not the workers - of the Polish construction industry; for this was in fact one of the main reasons for the Civil Platform to undertake it in the first place. After the Civic Platform will lose the upcoming elections, the bosses, always hungry for more, will support the Law and Justice without any qualms.

As a result, the stadiums have become venues of concentration and recruitment of new members of extreme right-wing groupings and into training areas of the soccer hooliganism. Instead of becoming centres of family entertainment and popularisation of culture, Polish stadiums are now functioning as academies of hatred for the young, who are just beginning their adult life but have already lost their hopes for a decent place for themselves in their own country. 
The xenophobic radicals, fed from both political hands, are gradually ceasing to be a marginal eccentricity of Polish political aesthetics, and a minor symptom of the psychopathology of Polish political life; they are now becoming an independent and vigorous political power. We do not yet have Budapest in Warsaw ${ }^{5}$, but we will not have to wait too long for it. The incident at the University of Wrocław and many similar ones demonstrate that Poland is dotted by various local infections of virulent nationalism not dissimilar to the Hungarian Jobbik.

That the promotion of Poland through soccer did not work was due not only to the desperate weakness of the Polish national team. However hard we work in order to organize efficiently the spectacles of the politicized sport, several incidents, like the one during Bauman's lecture, will suffice to annihilate the whole effort to dispel the centuries' long stereotype of Polnische Wirtschaft.

It is difficult to resist the conclusion that even though in antiquity the sport was the beginning of Greek democracy, in post-modernity the sport has become a beginning of the end of Polish democracy.

\section{A Systemic Helplessness}

Prior to the planned event commemorating the $150^{\text {th }}$ anniversary of German Social Democracy, members of the National Rebirth of Poland have been summoning each other via Facebook in order to stage its disruption and have formulated negative judgments concerning Zygmunt Bauman's past. Informed about the imminent danger, Leszek Miller, former prime minister and the chairman of the Polish Social Democratic Party, sent a letter to the Minister of Interior Affairs, Bartłomiej Sienkiewicz, requesting the protection of the event. An analogous intervention was undertaken by the German ambassador to Poland, who intervened at the Foreign Ministry. Eventually, the event was secured by the police, while Bauman and his companion were assigned personal bodyguards at the University's expense.

Shortly before the commencement of the meeting, the police officer in charge of the action at the University of Wrocław said that he was obliged to stay within the limits of law and that accordingly he could not intervene unless there were an immediate danger to life, health and property. To the argument that people who came to the lecture with an evident and announced intention to disrupt it are about to violate academic customs and rules of scholarly debate, he responded that the law does not protect these values. One of the main sources of the audacity of the Polish xenophobic groupings is the helplessness of law and its execution. It is enough to say that the Polish law protects all sorts of irrational beliefs and religious feelings, which incidentally are in Poland extremely easily hurt, but it does not protect the principles of scholarly discourse. 


\section{Radicalism at the Academia}

After the disruption of Bauman's lecture, some commentators said that xenophobic graduates of the academies of hatred now decided to enter the universities. Disruptions of the lectures of the philosophy professor Magdalena Środa and editor Adam Michnik have been invoked in support of such opinions. Attempting to restore some symmetry into the debate, Ryszard Legutko, a professor of philosophy and a current member of the European Parliament, has recalled an event at the University of Warsaw, in which he took part together with Norman Podhoretz; it was disrupted by a leftist group, and the police intervened there, as well. One may also add that several years back the philosopher Peter Singer from Princeton University was prevented by catholic activists from speaking at an ethical congress in Warsaw because of his stance on euthanasia. Desiderio Navarro, a Cuban intellectual, publisher and translator of Polish literature into Spanish, recently has fell a victim of a racist attack in Kraków; no such thing happened to him during his frequent visits to Poland over the past 35 years.

The opinion that nationalist xenophobia is only a beginning to enter the universities is misleading. If any ideology is nowadays prominent at the otherwise de-politicised academies, it is more frequently xenophobic than anything else. In fact, it has been present at Polish universities for a very long time now and feels quite at home there.

Shortly after the disruption of the event in question, a professor of the University of Wrocław and a representative of this ideological strand, who spoke, symbolically, under the monument of the king of Poland, Bolesław Chrobry ${ }^{6}$, described the organizers of Bauman's lecture as neo-Stalinists and accordingly called for the deStalinisation of the University. Two weeks after the disturbance, this call, eagerly seized on by the NOP, became a pretext and a slogan of a yet another demonstration in the public space of Wrocław. The NOP, now charged with a great momentum after its repeated "successes", staged it, once again, with impunity.

The call to de-Stalinise the University of Wrocław, formulated by this particular professor, was somewhat hilarious, firstly, because it has been expressed by a former member of the Polish communist party who changed his denomination into the "nationalist" one and is now apparently seeking a place on an electoral list of the Law and Justice party. The second reason is that there are no Stalinists at the universities anymore, for they have died out, while those, who somehow managed to survive, like this particular professor, changed their views radically because some time ago Stalinism ceased to be profitable. They have adopted the xenophobic outlook as nowadays it has become profitable.

Professors, like priests, are only human. No wonder, then, that some of them are doing and thinking only what is profitable for them. Some members of the Polish 
professoriate, frustrated by humiliating salaries, are seeking substitute satisfactions in the sphere of historical politics, expertly served to them by the Law and Justice. Being unable to enjoy recognition for their work, they are finding a vicarious yet unfailing satisfaction in the public extermination games against their academic comrades, who happen to hold different political views.

\section{The Problem of the Image}

Immediately after the incident, the Rector of the University of Wrocław was asked the question whether he intended to take any action leading to (i) bringing to justice the perpetrators of the disruption, which violated scholarly discourse and academic customs; (ii) investigation of the behaviour of academics of the University, who formulated abusive opinions about the invited guest and the organizers of the lecture; (iii) protection of freedom of scholarly investigations and openness of academic discourse through prevention of similar disruptions taking place in the future; (iv) salvaging the image of the University of Wrocław as a place of scientific work, open toward differing views; (v) protection of academic workers undertaking to organize extra-curricular scholarly events. One may now expect that as a result of such incidents scholars and public figures, as well as student of colour, may in the future decline the invitations to take part in events organised by the University of Wrocław or to enrol it.

The Rector's response has been a demonstration of helplessness because he has no legal means at his disposal to do any of those things. Shortly after this exchange, an assembly of rectors of the higher education institutions in Wrockaw adopted a resolution against the xenophobia, which has been an expression of their determination and equally of their powerlessness.

On the day of the incident at the University of Wrocław, the Minister of Higher Education, Mrs. Barbara Kudrycka, called the organizers asking for a private address of Bauman in order to send him a letter of apology. Sending such a letter is certainly a proper thing to do. The question remains whether Minister Kudrycka, before she leaves her office, will take any other action regarding the problem at hand. And if so, what kind of action? Will she bother herself to respond to the same questions, which have been addressed to the Rector of the University of Wrocław?

The present and the future minister of higher education will have to respond to a more general question, as well. Suppose anyone within the academia attempts to invite an eminent scholar who, apart from being a recognised professional, happens also to be a Jew, Arab, German, Russian, feminist, gay, lesbian, Muslim, protestant, Pentecostal, atheist, of a different colour, a social democrat, or a cosmopolite, will such a person have to take into account a possible threat from local xenophobes, who may happen to perceive the invited guest as persona non grata? Will it be necessary, for ever after, to ask for the police protection of any academic event, which local racists might happen to disapprove of? Will the Minister of the Interior place his 
troops at the rectors' disposal? Given the present circumstances, will the Ministry be ready to pick up the tab of the thus increased costs of deliberations in the humanities and social sciences?

The politics of the present regime towards higher education, which has generated an attitude of extreme asceticism while imposing a demand of innovation, in this context a rather absurd one, suggests that it will not be willing to cover the costs of amplified costs of scholarly research and higher education. This means that the space of free academic discourse, already much reduced by inadequate funding of research and academies, will rapidly shrink even further.

On the other hand, one is justified in suspecting that the present regime will be more willing to cover the cost of police protection of the universities rather than that of their adequate funding. Yet if the regime decides to protect the academies by police, itself heavily under-subsidised as well, it will have to acquiesce in the fact that scientific deliberations conducted in the shadow of police sticks and their smoothbore rifles may not be able to bring forth particularly bold or innovative results.

\section{The Venue}

This widely discussed incident took place in the city of Wrocław, which in 2011 won the title of the European Capital of Culture 2016. Wrocław's bid stressed the multicultural nature of the city and its openness to ethnic, cultural and religious diversity: "The fate of migrants is particularly close to the hearts of the inhabitants of Wrocław, descendants of people who, having lost the right to live in their native lands, made a foreign city and region their new home. (...) Polish Wrockaw is a place of constant fusion of diverse cultural horizons. Many visitors stop here for a longer time or remain here for good. New arrivals feel good in Wrocław as everybody in this city is a recent arrival from elsewhere: the present Polish inhabitants arrived from other parts of Europe themselves. The homo wratislaviensis is a multicultural creature, open to otherness, tolerant and cosmopolitan, like his habitat".

According to this document, various nationalities "live in Polish Wrocław in peace and mutual respect. This spiritual harmony is evidenced by the District of Mutual Respect, where followers of all religions pray side by side. Another example of peaceful coexistence of religions in Wrockaw is provided by the good neighbourly relations between the local Catholics and the Muslim minority, whose prayer room is next door to a Franciscan parish church. Ethnic and religious exclusivism is much weaker in Wrocław than in other parts of Poland, or Europe for that matter. The various social groups' ability to live in harmony and mutual respect is the only possible attitude in the face of the historical experience, which has been particularly cruel to the urban fabric of Wrockaw and to its residents. This is undoubtedly an evidence that the present-day people of Wrockaw know how to learn from the painful lessons taught by the history of their city". 
The event that the author of the present paper have helped to stage and participated in may be interpreted as belying everything that the citizens of Wrocław thought of themselves, what has been thought about it by people, such as Norman Davis, Roger Moorhouse and Gregor Thum, or what the author himself thought while he was writing the successful bid. The view of the gangsters howling confused and violent slogans in a university lecture room should have convinced him to revoke these beautiful but untrue words.

It did not. The first reason of that is that these words remain true of the vast majority of the citizens. Secondly, the bid contains very frank, even if painful, words about social problems, with which a significant portion of the population of the city, which is the second richest in Poland after Warsaw, has been coping with for a long time. It also points to well-defined groups which, as a result of the consistent unequal distribution of goods for the past two decades, have been suffering from social exclusion. Wroclaw's bid won the contest for the European Capital of Culture because it contains a diagnosis of the problem of exclusions, also from culture, as well as an outline of a programme to overcome them.

\section{Pouring the Concrete: In Poland and in Wroclaw}

Like every other city in Poland, Wrockaw spends huge amounts of money in order to build new public facilities. However, it is not true that its mayor is busy only with "pouring the concrete". The index of the city's expenditure on the "soft" cultural programmes is one of the highest in Poland, just as its cultural budget is. Besides, there is essentially no harm in pouring the concrete, especially in a city, which is still scarred by the war instigated by German Nazism and which has been consistently overlooked by the communist authorities, who were not quite sure whether the city would remain within Polish borders after the demise of the real-socialist regime in 1989.

The problem is that even though the city has a well-developed cultural infrastructure, it is difficult to induce its inhabitants to take advantage of its offer. The diagnosis contained in the city's bid for the title of the European Capital of Culture formulates this problem bluntly: barely 5-7 percent of the Wroclaw's citizens systematically take a (passive, i.e. spectatorial) part in cultural events. The bid elaborates categories of the public agoraphobia, interpassivity, and the commodification of the sphere of culture, and argues that these phenomena are commonplace across the whole country of Poland.

The problem thus lies not so much in pouring the concrete, but in the fact that the offer of the existing cultural infrastructure is being met with so little interest. Will the offer of the future cultural infrastructure, now under construction, attract greater attention? At the moment, there are no reasons to believe that it will. The point is that cultural education in Poland as a task of cultural institutions has been completely neglected. Cultural institutions have been subjected to the rules of the market and 
clientelism: they have to balance their books. At the same time, the present reduction of the number of pupils in schools, where cultural education should begin, instead of becoming a unique opportunity to raise the level of education, has been seized on as an opportunity for the lay-offs of teachers and closing down the schools.

The author of this paper trusts that the European Capital of Culture in Wrocław will be a spectacular success. One also hopes that the presently designed programme will include not only spectacular yet fleeting events, which will attract for a brief moment the attention of Wrocław's inhabitants, xenophobic ones among them, but that, in the spirit of the victorious application, it will also consist of projects, which will help to include the presently excluded social groups, xenophobic ones among them, into the process of a common restoration of a positive image of Wrocław.

\section{German Responsibility}

During deafening protestations of the nationalists against Zygmunt Bauman, some demonstrators raised their hands in the Nazi salute. For the Germans present in the audience this unashamed emulation of the Nazi symbols by the Polish nationalists within the open public space has been a shock, the Consul General sat in the first row of the audience with his face ashen from fear.

The spirit of Nazism has not been irrevocably buried in Germany. Symbols of the political culture concocted by Hitler's spin-doctors turn out to be more lively than anyone expected. With their own neo-Nazism reborn, Germans must now feel as if the package, sent by their grandparents, has been finally delivered with several decades' delay. Most of them dump this package into the trash bin; some of them, ashamed, bury it in a cellar; some store its contents with nostalgia. But some of them, including the youngest, open the package with curiosity and set free the noxious elements contained in it. But this Nazi package, against the intention of its sender, is now being received also by descendants of the nation, which suffered from the Nazis' particular cruelties. In this way, the Polish-German reconciliation, usually perceived through the gestures of political correctness, turns out to possess another surprising dimension, an "incorrect" one, and, as a rule, hidden from the public view.

Bauman is a severe critic of the present economic and social order. He believes that the present social and economic regime in Poland and in the world is deeply unjust, leads to exclusions and grows within itself seeds of its own demise. In the lecture, he said that political parties, which now pretend to represent the ideals of the Left, like the German SPD and the Polish SLD, should be held accountable for the emergence of this order, for they have betrayed the leftist values and instead became societies of mutual admiration with business bosses. He meant especially what Gerhard Schröder, known as Genosse der Bosse [Comrade of the Bosses], had done to the SPD, of which he was a leader. Bauman expressed this judgement in the same University room, in which precisely ten years earlier Chancellor Schröder represented Germany during a meeting of the so-called Weimar Triangle, a consultation forum for political leaders of France, Germany and Poland. 
The Poles are entitled to expect that Germans, especially from the present SPD, should take a clear stance concerning what is going on in their own country. They should also be aware that the Polish brand of Nazism is not only an internal problem of Poland; it is also a problem of contemporary Germany as well as of Europe as a whole.

\section{Party of Order and the status quo}

When the author of the present paper insisted that the authorities of the University of Wrocław summon the police in order to protect an academic event, and then insisted that the commander of the police troops removes the troublemakers, he suddenly remembered Arthur Schopenhauer, who pointed out to the police the most convenient place for them to shoot at the revolutionary masses during the Spring of Peoples in 1948. He also remembered Karl Marx's ironic remarks from his 18th Brumaire: yes, I acted as a representative of the Party of Order who called the police to protect the status quo.

The point is, however, that the author of this paper is not really convinced that the present political and economic order in Poland deserves to be protected. Bauman ingeniously and critically diagnoses the system which products and symptoms are precisely those people who came to vilify him. And he seeks for ways to reform it. That is why he was invited to speak.

It would seem that extremist groupings in Poland also demand a change of the social order, just as Bauman does, and that the difference between them lies only in methods advocated. But this is not so. The present Polish radicalism is nationalistic, patriotic, xenophobic, homophobic, anti-feminist, anti-communist, anti-Semitic, anti-German, anti-European, anti-intellectual, etc. In a word, it stands for everything that is officially suppressed by the liberal and tolerant elites striving to impose upon society their own version of constraints of decency. In this sense, the Polish radicalism, in its exhibitionism and pornographic obscenity, may be perceived as a symptom of social revolt.

The question of a more just distribution of wealth is not, however, addressed by its members. In this sense, the Polish radicalism is thoroughly conservative. It does not strive towards a change of the political system because it draws from it all its strength and moves within it unperturbed. The whole raison d'être of the Polish radical movements is to excite disorders, during which their members can demonstrate their own strength, and subsequently to use it as a bargaining argument and a political commodity. This is the whole point of politics understood as a spectacle within which to be is to be perceived. The present system is needed by them as a venue or a scene upon which to perform their rituals of brutality and hatred. They will not find any better one. For this reason precisely, they need the cosmopolites, Jews, Arabs, Blacks, agents, communists, Stalinists, Germans, Russians, Europeans and egg-heads in order to stage their rituals of hate. They are employing this inconsistent ideological 
conglomerate because it guarantees them an inexhaustible supply of objects for their hatred. Should the objects, per impossible, become in short supply, they would create them without much effort. For the time being, their strength is basically the strength of a spectacle; for this reason, it is only an appearance of strength. They will become really dangerous when they understand this. And they are just one step from it. One has only to wait to see whether they will summon the courage to make this step.

It has become nowadays a commonplace of political criticism that the contemporary political system has been transformed into a pathetic caricature of democracy. The slogan of democratic participation is only a smokescreen for the growing oligarchisation of societies and despotisation of politics at all its levels. In the sphere of the economy, the Civic Platform excels in cultivating this art and elevated it to new levels of sophistication through managing the assets of the country in order to create further inequalities and without bothering about their social costs. Thus, the situation of a deep imbalance of social structure created cannot be remedied overnight; it has gone way too far. For this reason, the Finance Minister Vincent Rostowski will now have to find a place for a new rubric on the expenditure side of his budget: "the costs of social peace". The longer he delays this, the more hefty sums he will have to put in this rubric in the future. Such a rubric will have to be filled also by the Minister of Finance in any Law and Justice government.

\section{Cracked Crust}

The six post-war decades in Poland have brought disenchantment with the leftist utopia. The past two decades of the transformation have brought disenchantment with conservative liberalism. Radicalism in Poland destroys politics and dispels the hope for social peace. It overwhelms the churches and universities, the last enclaves of relative decency. What, then, has the future in store for us? Bertrand Russell has compared civilised life to a dangerous walk on a thin crust of barely cooled lava, which at any moment may break and let the unwary sink into its fiery depths. John Gray has argued that the best that flawed and potentially wicked human creatures can hope for is a commitment to civilised constraints that will prevent the very worst from happening: a politics of the least worst ${ }^{7}$.

The problem is that in Poland the crust of constraints of decency turned out to be very thin and has just cracked again. The lava flowing from below refuses to cool down by itself, nor it will be cooled off any time soon, or easily.

7 The wording comes from Simon Critchley's review of John Gray's The Silence of Animals, Los Angeles Review of Books, June 2nd, 2013. 